Jurnal Agribis

Vol. 7, No.2, Oktober Tahun 2021

\title{
ANALISIS PERAN KELOMPOK TANI DALAM UPAYA PENINGKATAN EKONOMI PERTANI DI ERA PANDEMI COVID-19
}

\author{
Mufida Diah Lestari ${ }^{1}$ \\ Program Studi Agribisnis, Fakultas Pertanian, Universitas Tulungagung \\ 4 \\ E-mail: Mufida.dl85@gmail.com
}

\begin{abstract}
ABSTRAK
Indonesia memiliki daerah pertanian yang luas, penduduk juga masih memiliki mata pencaharian sebagai petani, namun saat sekarang ini dunia pertanian mengalami nilai surut akan penghasilan yang diterima oleh para petani. Hal ini dikarenakan hasil dari pertanian tidak mendapatkan respon yang baik dari konsumen, karena harga jual di masyarakat saat sekarang mengalami penurunan nilai daya beli pada masyarakat.

Era pandemic Covid-19 menjadi salah satu faktor utama, karena dari efek kondisi pandemic saat ini sangat berpengaruh di hampir seluruh lini sektor di masyarakat. Pertanian juga menjadi salah satu sektor yang mengalami penurunan nilai pendapatannya. Biaya operasional mengalami peningkatan nilai yang cukup tinggi sehingga membuat harga jual mengalami peningkatan, tetapi karena kondisi ekonomi di era pandemi sekarang ini sangat membuat masyarakat memiliki tingkat konsumsi yang cukup rendah sehingga banyak dari hasil pertanian yang tidak dapat terjual dengan maksimal. Oleh sebab itu sekarang diperlukan kelompok yang menjadi tangan panjang dari petanisehingga dapat menampung hasil pertanian dari masyarakat petani untuk dapat didistribusikan kepada masyarakat dengan harga yang baik bagi para petani. Peran kelompok tani cukup besar diantaranya adalah kelompok dapat memberikan
\end{abstract}

Kata Kunci: kelompoktani,peningkatan ekonomi,covid-19

\section{ABSTRACT}

Indonesia has a large agricultural area, the population also still has a livelihood as farmers, but currently the agricultural world is experiencing a receding value of the income received by farmers. This is because the results of agriculture do not get a good response from consumers, because the selling price in society is currently experiencing a decrease in the value of purchasing power in the community.

The era of the Covid-19 pandemic is one of the main factors, because the effects of the current pandemic condition are very influential in almost all sectors of society. Agriculture is also one of the sectors experiencing a decline in the value of its income. Operational costs have increased in value which is high enough to make selling prices increase, but due to economic conditions in the current pandemic era, people have a fairly low level of consumption so that many agricultural products cannot be sold optimally.

Keywords: farmer groups, economic improvement, covid-19 


\section{PENDAHULUAN}

\section{Latar Belakang}

Indonesia merupakan salah satu negara yang terdampak pada pandemic covid-19. Hampir semua lini kehidupan masyarakat dan perekonomian mengalami perubahan yang cukup besar. Sektor pertanian juga menjadi sektor yang sangat melemah di era pandemic, hal tersebut dikarenakan daya beli masyarakat saat ini mulai melemah sehingga mempengaruhi penghasilan yang diperoleh petani. Tidak hanya itu, pandemi covid-19 juga memberi dampak biaya operasinal dunia pertanian naik cukup tinggi, hal tersebut juga berpengaruh pada nilai dari hasil pertanian.

Sektor pertanian yang semakin melemah menjadikan penurunan tingkat kesejahteraan petani dan keluarga petani menurun. Penurunan ini tidak hanya pada proses pasca bercocok tanam, namun berpengaruh dari mulai hulu sampai hilir. Petani mengalami kesulitan untuk memulai proses tanam, karena keterbatasan modal yang mereka miliki. Modal tersebut diperlukan pada setiap proses tanam berlangsung hingga panen.

Kelompok tani menjadi salah satu wadah bagi para petani untuk dapat bekerja sama dalam sebuah organisasi yang memiliki tujuan meningkatkan kesejahteraan keluarga petani. Namun, saat sekarang ini banyak kendala yang muncul sehingga menyebabkan beberapa kelompoktani kurang begitu berjalan sesuai dengan tujuan yang diinginkan.

\section{Tujuan}

Tujuan dari penelitian ini adalah untuk melihat seberapa besar kelompok tani memberikan dampak positif dalam hal peningkatan ekonomi petani di era pandemi. Kelompok tani menjadi salah satu organisasi non formal yang menjadi wadah para petani untuk meningkatkan perekonomian.

\section{METODE PENELITIAN}

Peneliti dalam penelitian ini menggunakan jenis penelitian field research (penelitian lapangan). Sedangkan sifat penelitian ini dengan menggunakan penelitian deskripsif kualititatif, yakni penelitian yang menggambarkan secara tepat sifat-sifat individu, keadaan, gejala atau kelompok tertentu untuk menentukan frekuensi atau penyebaran suatu gejala atau frekuensi adanya hubungan tertentu suatu gejala lain dalam masyarakat. Populasi dalam penelitian ini adalah anggota kelompok tani di Kecamtan Campurdarat Kabupaten Tulungagung. Sampel dari penelitian ini merupakan bagian dari jumlah dan juga karakteristik yang dimiliki oleh populasi tersebut. Sumber data diperoleh dari sumber data primer dan juga sekunder. Sedangkan metode pengumpulan data, peneliti ,melakukan observasi, wawancara dan juga dokumentasi. Pada analisis data, peneliti menganalisis dengan melakukannya dengan turun kelapang kemudian menyusunnya secara sistematis berdasarkan dari hasil wawancara dengan responden dan juga catatan lapang dan juga dokumentasi. Tujuan dari peneliti adalah agar supaya apa yang telah didapatkan dilapang dapat diterima dan dipahami menjadi sebuah informasi baru baik oleh peneliti itu sendiri maupun orang lain. 


\section{HASIL DAN PEMBAHASAN}

Hasil dari penelitian ini menjukkan bahwa kondisi kesejahteraan masyarakat secara simbolik sudah Nampak dari luar, sedangkan langkah-langkah kelompok tani apabila dilihat dari sisi keorganisasiannya sudah memiliki perencanaan yang baik dalam segala bentuk penyusunan programnya namun belum dapat terwujud dengan baik dan juga efektif. Hal ini disebabkan oleh kurangnya campur tangan pemerintah serta pihak yang seharusnya ikut bertanggung jawab dalam lembaga tersebut. Hal lain yang menjadi kendala adalah kurangnya kesabaran oleh masing-masing anggota kelompok tani dalam menumbuhkan kerjasama dalam pertanian. Peran serta pemerintah juga menjadi salah satu tolak ukur keberhasilan dari kelompok tani, karena perhatian serta pembinaan dari pemeritnah baik ditinggal desa maupun kabupaten akan sangat berpengaruh akan kemajuan kelembagaan tersebut.

Kelompok tani memiliki fungsi sebagai tempat untuk belajar, yakni wadah untuk mengajar bagi anggotanya untuk upaya meningkatkan pengetahuan, keterampilan dan juga sikap serta tumbuh kembang jiwa kemandirian dalam usaha tani sehingga memeberikan dampak pada peningkatan produkstiviitas petani, peningkatan pendapatan dan juga peningkatan kesejahteraan petani meski dalam kondisi covic 19 yang belum usai. Kelompok tani juga mampu menjadi tempat menjalin kerja sama guna memperat kerja sama antar petani didalam kelompok tani dan kelompok lain dengan tujuan usaha taninya menjadi lebih efesien serta lebih mampu menghadapi tantangan, hambatan, dan gangguan.

Kegiatan yang ddilakukan oleh kelompoktani di daerah penelitian diantaranya melihat beberapa perubahan terkait beberapa hal, diantaranya adalah:

a. Modal, dalam hal permodalan terdapat perubahan kepemilikan modalan petani yakni sebelum bergabung menjadi anggota kelompok tani modal yang dikeluarkan merupakan modal sendiri jika kekurangan modal

b. Simpan pinjam, petani dapat melakukan simpan pinjam anggota kepada kelompok tani dan hal tersebut dapat menguntungkan petani.

c. Munculnya motivasi dari anggota dalam mengembangjan usahanya dan menambah penghasilan. Sehingga petani menjadi memiliki memiliki motivasi untuk lebih maju dalam bercocok tanam. Jika melihat dari besarnya antusias dan keutungan tersebut akan memunculkan perubahan pendapatan petani.

Berdasarakan hasil wawancara yang tengah dilakukan oleh peneliti adalah, banyak kegiatan yang dilakukan kelompok tani di daerah tersebut diantara adalah adalah:

a. Pertemuan rutin anggota kelompok tani dan juga pengurus, pertemuan ini dilakukan seminggu dua kali pertemuan dan dilakukan pada malam hari dengan asumsi semua anggota kelompok tani dapat mengikuti pertemuan tersebut sehingga dapat mengikuti perkembangan informasi terakait kelompok tersebut.

b. Pertemuan rutin anggota dengan penyuluh pertanian, pertemuan ini dilakukan dalam jangka waktu satu bulan satu kali dilakukan dengan asumsi jika terjadi permasalahan sewaktu oleh petani aka dilakukan pertemuan khusus tentang permasalahan yang terjadi pada masa itu. 
c. Pelatihan ketrampilan kepada petani sehingga mengurangi pengangguran dan meningkatkan pendapatan keluarga petani, pelatihan yang pernah dilakukan didaerah penelitian adalah pelatihan bagi para ibu petani yang biasanya mereka hanya sebagai ibu rumah tangga agar dapat berpoduktif sehingga dapat membantu peningkatan ekonomi petani.

Dalam pertemuan tersebut tujuannya adalah terjalinnya komunikasi antar anggota, anggota dengan pengurus dan juga dapat memberikan informasi mengenai permasalahan yang ada dan juga inovasi-inovasi baru sehingga akan mempermudah petani dalam melakukan cocok tanam.

Kendala yang selama ini dialami oleh kelompok tani di daerah penelitian adalah sebagai berikut:

a. Kurangnya peran serta petani dalam usaha pemajuan kelompoktani

b. Kurangnya koordinasi antara pengurus, anggota kelompok tani dan steakholder.

c. Kurangnya sosialisasi akan kegiatan-kegiatan kelompok tani diwilayah tersebut.

d. Kurangnya peran pemerintah dalam merespon keterlibatan pemerintah dalam upaya peningkatan ekstistensi kelompok tani.

e. Petani masih enggan bergabung dalam kelompok tani karena merasa mereka tidak memiliki waktu luang untuk mengikuti kegiatan organisasi.

Kegiatan yang dilakukan oleh kelompok tani digunakan sebagai wadah untuk memelihara akan peningkatan pengetahuan, ketrampilan dan gotong royong dalam usaha tani anggotnya dalam menyediakan prasarana produksi (peminjaman alat produksi, dan tempat pemberdayaan), peminjaman modal usaha tani, motivasi peningkatan produksi dan gotong royong bersama anggota kelompok tani.

Musyawarah dilakukan setiap penentuan keputusan dalam kelompok tani dengan harapan supaya terjalin rasa kebersamaan sehingga dakan didapatkan hasil musyawarah berdasarkan atas persamaan pendapat sehingga memiliki nilai keadilan. Kesepakatan yang diperoleh merupakan hasil dari kesepakatan bersama dan tidak ada unsur paksaan didalamnya, sehingga semua anggota dapat melakukan hasil keputusan dengan penuh tanggung jawab. Kegiatan masyarakat dalam hal ini seperti yang dilakukan dalam kelompok tani tersebut mampu mendorong kesejahteraan hidup masyarakat petani. Peran dari kelompok tani yang dijalankan kelompok tani didaerah penelitian tersebut dalam upaya meningkatkan pendapatan ekonomi masyarakat menjadi sebuah kegiatan yang memiliki nilai positif. Hal tersebut sesuai dengan teori kesejahtereaan dalam ekonomi yaitu kesejahteraan merupakan hasil kejra seluruh elemen yang ada dimasyarakat, baik pemerintah, keluarga maupun masyrakat. 


\section{KESIMPULAN DAN SARAN}

\section{KESIMPULAN}

Simpulan yang dapat diperoleh dari hasil studi lapang yang dilakukan oleh peneliti mengenai peran kelompok tani dalam upaya peningkatan ekonomi petani diera padnemi covid 19 adalah sebagai berikut:

1. Program yang dijalankan kelompok tani didaeran penelitian dapat diketahui melalui kegiatan yang dilakukan dengan mengadakan pertemuan rutin. Pelatihan ketreampilan kepada kelompok Wanita tani dan juga memberikan fasilitas program simpan pinjam yang dapat dijadikan sebagai modal oleh petani. Bentuk dari simpan pinjam ini dapat berupa uang, namun juga ada fasilitas yang diberikan kepada petani berupa peminjaman sarana produksi pertanian berupa alat berat, pemebrian subsidi pupuk dan lain sebagainya yang bertujuan untuk memudahkan petani dalam proses bercocok tanam. Sehingga besar harapan dari kelompok tani tersebut meningkatnya perekonomian petani meski dalam kondisi pandemic covid 19.

2. Kelompok Tani memiliki peran dalam upaya peningkatkan pendapatan ekonomi petani. Peran dari kelompok itu sendiri adalah sebagai tempat petani menyalurkan aspiranya dan juga tempat mereka bermusyawarah untuk Bersama bekerja sama dalam upaya peningkatan mutu dari Bertani mereka dengan memberikan informasi-inofrmasi yang memberikan manfaat bagi petani. Kegiatan lain adalah mengadakan kegiatan pemberdayaan ekonomi dan juga berkembangnya pengetahuan, ketrampilan dan kegotong royongan berusaha tani. Sehingga dari kegaitan yang dilakukan oleh kelompok tani tersebut memiliki sebuah garis lurus sesuai dengan keinginan petani. Para petani akan merasa terbantu dan dapat memecehakan solusi yang mereka hadapi dan dapat membantu petani dalam meemcahkan permasalahan yang dihadapi.

3. Kelompok Tani dapat berpean dalam apabila muncul peran pemerintah dan masyarakat yang stretegis memberikan dukungan akan keberadaaan kelompok tani sehingga kelompok tani mampu berjalan bersinergi dengan beberapa elemen masyarakat dan juga berjalan Bersama dengan tidak mengesampingkan kaidah-kaidah yang ada dalam pemerintahan dan juga dalam menyongsong keterlibatan kelompok tani dalam perannya sebagai salah satu organisasi masyarakat yang mampu memberikan dorongan dan juga stimulus akan kemajuan ekonomi petani guna menghadapai eran covid 19 agara dapat tetap berjalan dan berkembang sebagaimana mestinya. 


\section{S A R A N:}

Saran yang dapat diberikan oleh penulis dalam peran kelonpok tani dalam usaha penignkatan perekonomian petani di era covid '19 di daerah penelitian adalah sebagai berikut:

1. Bagi pelaksanaan kegiatan Kelompok Tani alangkah baiknya dapat memberikan penambahan usaha supaya dapat meningkatkan pendapatan anggota, terjalinnya koordinasi antara anggota kelompok dalam melaksanakan usaha kelompok, kerjasamaa yang baik dan pembagian tugas yang lebih teratur. Diperlukan sebuah perbaikan manajemen kelompok supaya lebih baik lagi.

2. Kelompok Tani dalam meningkatkan pendapatan masyarakat (anggota kelompok tani) merupakan sebuah kegiatan yang positif. Maka dalam melaksanakan setiap kegiatan supaya kelompok tani lebih menerapkan kaidah-kaidah yang ada dalam hal memanajemen kegiatan, memanajemen sumber daya manusia serta yang sangat penting juga adalah memanajemen keuagan. 


\section{DAFTAR PUSTAKA}

Ahamad Tohardi, Manajemen Sumber Daya Manusia( Bandung: Mandar Maju, 2002).

Azzam Asfiansyah Hakam, "Peran Kelompok Tani Terhadap Usaha Peningkatan Pendapatan Anggota Melalui Program Kemitraan Usahatani (Studi Kasus Kelompok Tani "Sri Mulyo" Kecamatan Sukun, Kota Malang)", (Malang 2014).

Bahruddin, Rudy, Ekonomika Otonomi Daerah (Yongyakarta: UPPSTM YK, 2002).

Departemen Pendidikan Nasional, Kamus Besar Bahasa Indonesia, edisi III, (Jakarta: Balai Pustaka, 2002).

Faisal H. Basri, Perekonomian Indonesia (Jakarta: Erlangga, 2002).

Gunawan Sumodiningrat, Membangun Perekonomian Rakyat (Yongyakarta: Pustaka Pelajar, 1998).

Kartini Kartono, Pengantar Metodelogi Reasearch Sosial, Cet Ke V ( Bandung: Madar Maju, 2006).

Lipsey, Pengantar Ilmu Ekonomi (Jakarta: Erlangga, 1999).

Majelis Permusyawaratan Rakyat Republik Indonesia, Undang-Undang Dasar Negara

Michael p. Todaro dan Stephen C. Smith, Pembangunan Ekonomi Edisi Kesebelas Jilid 1( Jakarta: Erlangga, 2011).

Mohamad Ikbal, "Peranan Kelompok Tani Dalam Meningkatkan Pendapatan Petani Padi Sawah Di Desa Margamulya Kecamatan Bungku Barat Kabupaten Morowali". e-J. Agrotekbis Vol. 2 No. 5 (Oktober 2014).

Munawar Ismail, dkk, Sistem Ekonomi Indonesia Tafsiran Pancasila dan UUD 1945, (Jakarta: Erlangga, 2014).

Nasri, "Peranan Kelompok Tani Dalam Peningkatan Kesejahteraan Masyarakat Desa Ulujangang Kec. Bontolempangan Kab. Gowa". Skripsi Universitas Islam Negeri Alauddin Makasar (Februari 2013).

Nunung Nurwati, “Kemiskinan: Model Pengukuran, Permasalahan dan Alternatif Kebijakan”. Jurnal Kependudukan Padjadjaran, Vol. 10 No. 1 (Januari 2008).

Pamertan, Pedoman Pengembangan Usaha Agribisnis Pedesaan (Jakarta: Departemen Pertanian RI, 2015).

R. Soediro Mangundjojo, "Sosial Ekonomi Masyarakat” (Jakarta: Direktorat Jendral, 1999).

Suharsimi Arikunto, Prosedur Penelitian Masyarakat : "Suatu Pendekatan Masyarakat", Cet Ke vi (Jakarta: Gramedia pustaka utama, 2003)

Undang-Undang Republik Indonesia No. 11 Tahun 2009 Tentang Kesejahteraan Masyarakat. 